\title{
Dodonaea viscosa Jacq: A Medicinal Plant with Cytotoxic Effect on Colon Cancer Cell Line (HT-29)
}

\author{
Oscar Herrera-Calderon ${ }^{*}$ (D), Md. Habibur Rahman² (D), Gilmar Pena-Rojas ${ }^{3}$ (iD \\ and Vidalina Andia-Ayme ${ }^{4}$ iD
}

\begin{abstract}
${ }^{1}$ Department of Pharmacology, Bromatology and Toxicology, Faculty of Pharmacy and Biochemistry, Universidad Nacional Mayor de San Marcos, Lima, Peru. ${ }^{2}$ Department of Pharmacy, Southeast University, Banani, Dhaka - 1213, Bangladesh. ${ }^{3}$ Laboratory of Cellular and Molecular Biology, Biological Sciences Faculty, Universidad Nacional de San Cristobal de Huamanga, Portal Independencia 57, Ayacucho - 05003, Peru. ${ }^{4}$ Food Microbiology Laboratory, Biological Sciences Faculty, Universidad Nacional de San Cristobal de Huamanga, Portal Independencia 57, Ayacucho - 05003, Peru.
\end{abstract}

\begin{abstract}
Dodonaea viscosa (Family: Sapindaceae) is a medicinal plant that has been used as anti-rheumatic and bone pain in Peru as a folk remedy. Ethanol extract obtained from $D$. viscosa leaves was partitioned as $\mathrm{n}$-hexane fraction; chloroform fraction; ethyl acetate fraction; $n$-butanol fraction and aqueous fraction. Phytoconstituents from $D$. viscosa leaves were evaluated by using chemical reagents to identify the presence of each phytochemical. In addition, a cytotoxic effect was determined by the Sulforhodamine B (SRB) test. The results showed that the ethanol extract and ethyl acetate fraction of leaves had the highest variety of phytoconstituents. The ethanol extrac of leaves exhibited a major inhibitory effect compared to different fractions in human colon cancer cells (HT-29). From these assays, it is concluded that $D$. viscosa does not possess any detectable cytotoxic effect on epidermal cells from mouse (3T3), and a slight cytotoxic effect against HT-29 tumor cells compared to 5-FU. This species could appear like a good source of herbal medicine in colorectal cancer disease.
\end{abstract}

Keywords: Dodonaea viscosa, colon cancer, flavonoids, phytochemicals, cytotoxic activity

*Correspondence: oherreraca@unmsm.edu.pe; +51 956550510

(Received: July 27, 2020; accepted: September 18, 2020)

Citation: Herrera-Calderon O, Rahman MH, Pena-Rojas G, Andia-Ayme V. Dodonaea viscosa Jacq: A Medicinal Plant with Cytotoxic Effect on Colon Cancer Cell Line (HT-29). J Pure Appl Microbiol. 2020;14(3):1927-1934. doi: 10.22207/JPAM.14.3.31

(C) The Author(s) 2020. Open Access. This article is distributed under the terms of the Creative Commons Attribution 4.0 International License which permits unrestricted use, sharing, distribution, and reproduction in any medium, provided you give appropriate credit to the original author(s) and the source, provide a link to the Creative Commons license, and indicate if changes were made. 


\section{INTRODUCTION}

Colon cancer or colorectal cancer (CRC) ranks as third cancer in incidence and the second in mortality worldwide ${ }^{1}$. CRC is the result of uncontrolled cell growth in a specific part of the large intestine produced by multiple factors, which are involved in the development of colorectal cancer such as excessive alcohol consumption, family history, lack of physical activity, high-fat diets with no fiber old age, red meat, diabetes, and inflammatory bowel diseases (IBD), including ulcerative colitis and other chronic diseases linked to large intestine ${ }^{2}$. In 2018, the Global Cancer Observatory (GLOBOCAN) estimates 18.1 million new cancer cases as well as 9.6 million cancer deaths ${ }^{3}$.

The relationship between human beings and nature is very known. Human beings get medicine from nature because they are continuously digging the knowledge from different plants and their effectiveness as treatment of several non-transmissible diseases ${ }^{4}$. Most of the phytochemicals are bioactive and can be used in the production of synthetic medicine or druggable options in the antitumor drug discovery.

Screening of drug in colon cancer studies have been carried out on HT-29, HCT116, and Caco- 2 cells. HT29 is known as human colon adenocarcinoma cell line and shows a biochemistry of mature intestinal cells. Additionally the medicinal plants used as anti-inflammatory coming from the ethnopharmacological knowledge and they are tested on this type of tumor cells, taking into account its toxicity and effective concentration $^{5}$. On the other hand, the factors secreted by HT29 cells are growth factors, plateletderived growth factor, chemokines, immunemodulatory and pro-inflammatory cytokines ${ }^{6}$. Studies of natural products as flavonoids ${ }^{7}$ and terpenes ${ }^{8}$ have demonstrated regulation of these components linked to the inflammation process.

The discovery of new drugs for tumor treatment is focused on its tolerability and safety profile, some of them were found in natural sources ${ }^{9}$. The preclinical phase of antitumor drugs generally are tested in-silico and in-vitro, and its properties can vary such as anti-mutagenic, anti-proliferative, cytotoxic, and pro-apoptosis. Therefore, validation of any it must be alternative therapy based on medicinal plants has gained much interest due to its availability, accessibility, affordability and have less side effects ${ }^{10}$. On the other hand, a clinical trial is the last step to ensure its use in the population. Several medicinal plants of diverse families have therapeutic properties, which improve and decrease high rates of morbidity and mortality.

Dodonaea viscosa Jacq. (Family: Sapindaceae) is a shrub, rarely a small tree, and widely distributed in tropical and subtropical areas of both hemispheres ${ }^{11}$. It is used in folk medicine as a febrifuge, a diaphoretic drug, and for the treatment of rheumatism, gout, inflammations, swelling, and pain in Asian countries. According to Peruvian folk medicines, $D$. viscosa leaves (Fig. 1) are used as an anti-inflammatory and analgesic herbal medicine. In the Apurimac region, D. viscosa is known as "chamana" and grows at 2300 meter above the sea level (m.a.s.l). Several flavonoids, diterpenoid acids and saponins have been found

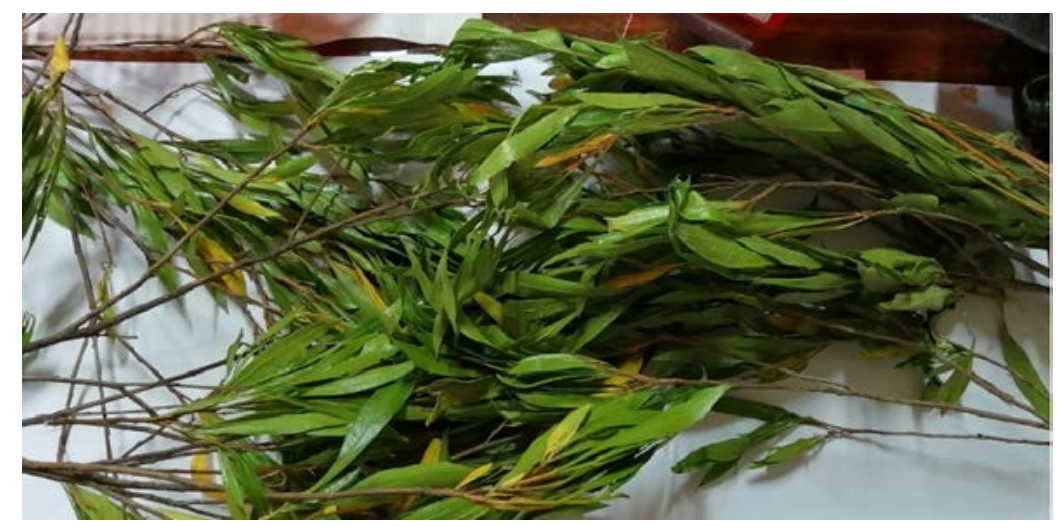

Fig. 1. Aerial parts of Dodonaea viscosa Jacq.

Journal of Pure and Applied Microbiology 
in this species such as 3,3',4',5,7-pentahydroxy flavane, hautriwaic acid, 4-methoxylstigmasterol, 5-hydroxy-7,3'4'-trimethoxy-6-acetoxy-3prenylflavone, dodonic acid, dodoviscins ${ }^{12}$ and other phytocompounds determined in the literature (Fig. 2a and Fig. 2b). Nowadays, the cytotoxic effect of Dodonaea viscosa in vitro has not been tested for colon cancer. We proposed to validate the medicinal potential of this plant, evaluating the different fractions obtained from Dodonaea viscosa leaves on HT-29 tumor cells.

\section{MATERIALS AND METHODS}

Chemicals

Dulbecco's Modified Eagle Medium (DMEM), Sulforhodamine B (SRB), and fetal calf serum were purchased from Sigma-Aldrich, USA. Other required chemicals of ACS grade were obtained from the local market of chemical companies.

\section{Plant material}

Aerial parts of Dodonaea viscosa were collected from Chalhuanca, Aymaraes, Apurimac

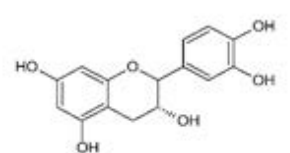

$3,3: 4 * 5,7-$ Pentahydroxy flavane

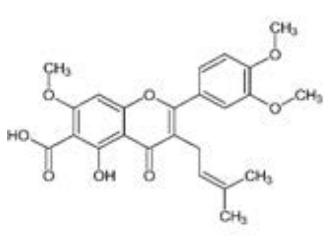

5-Hydroxy-7, $3^{\prime} 4^{\prime}$-trimethoxy-6acetoxy-3-prenylflavone

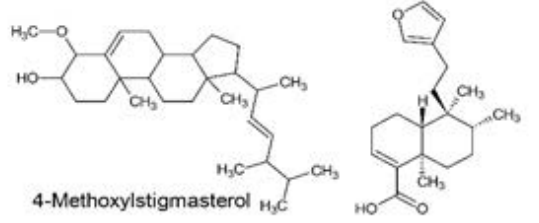

(+)-hardwickiic acid

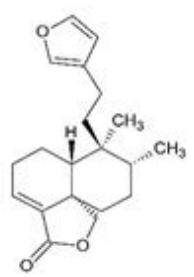

hautriwaic lactone

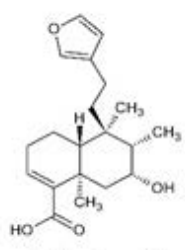

Dodonic acid

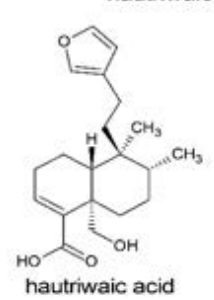

hautriwaic acid<smiles></smiles>

methyl dodovisate $\mathrm{B}$

$5 \alpha$-hydroxy-1,2-dehydroxy-5,10-dihydroprint-zianic acid methyl ester<smiles>O=c1c(O)c(-c2ccc(O)c(O)c2)oc2cc(O)cc(O)c12</smiles><smiles>COc1cc(O)c2c(c1OC)O[C@H](c1ccc(O)cc1)CC2=O</smiles>

5,4'-dihydroxy-7,8-dimethoxyflavanone<smiles></smiles><smiles></smiles>

aliarin

5,7,40-tritydroxy-30-(4-hydroxy-3-methylbuty)-50-(3-m $\mathrm{CH}_{3}$ ethylbut-2-eny)-3,6-dimethoxylavone

Fig. 2a. Chemical constituents reported in Dodonaea viscosa Jacq leaves 


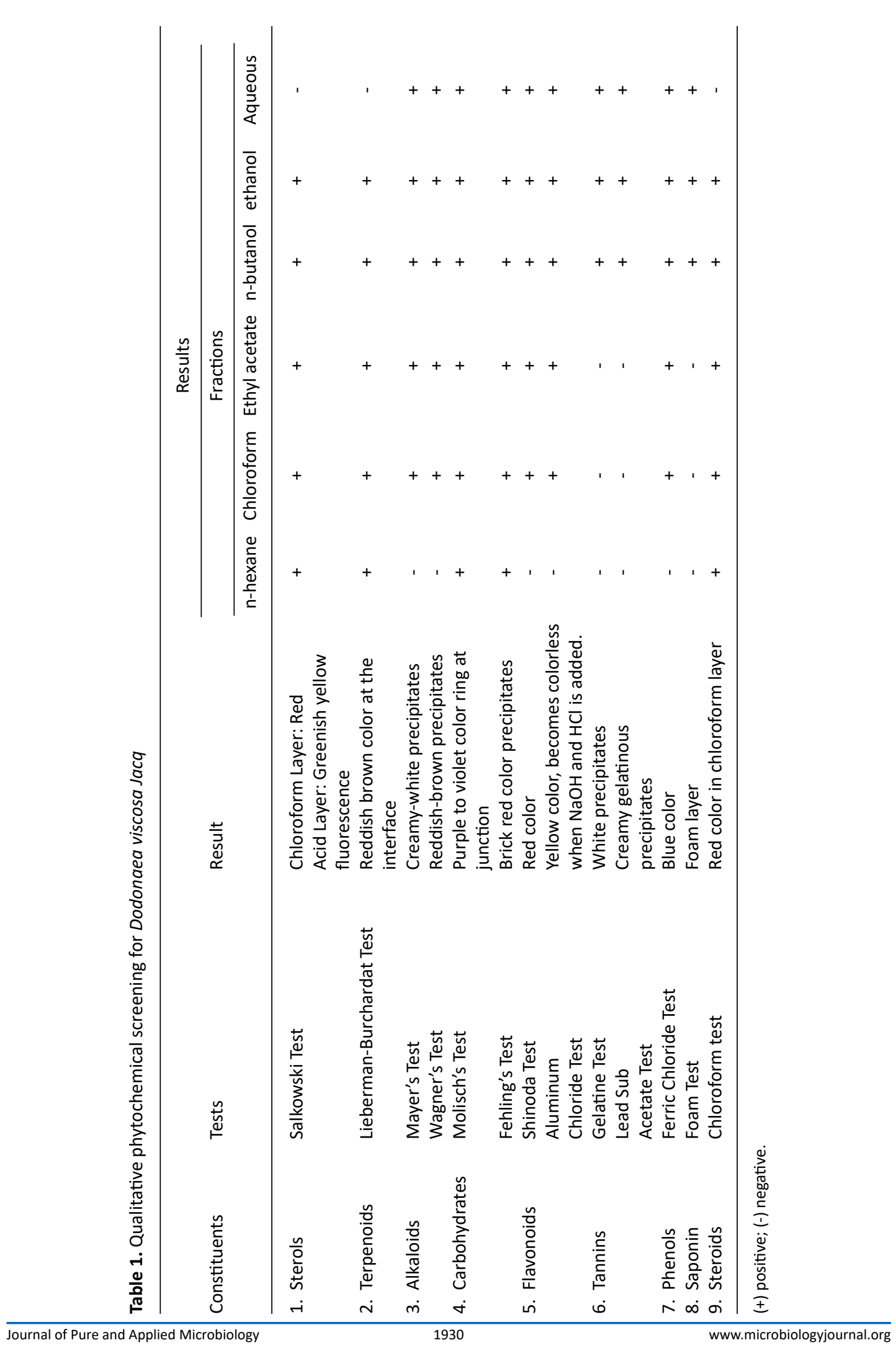


region, Peru during the month of July 2019 and it was successively identified by Mg. Asuncion A. Cano Echevarria, a voucher specimen (Id 125-USM2019) was deposited at the Museum of the Natural History of the Universidad Nacional Mayor de San Marcos (UNMSM, Lima, Peru).

Extraction and fractionation of plant materials

The aerial parts ( $\sim 00 \mathrm{~g}$ ) were dried, powdered, and macerated for 7 days with $96 \%$ ethanol at room temperature and then filtered with Whatman filter paper Grade 1. The filtrate was concentrated by removing the solvent by using rotary evaporator under vacuum at $40^{\circ} \mathrm{C}$ and 80 RPM, resulting 50.2 grams of dark green ethanolic extract. Ethanolic extract was prepared with 600 $\mathrm{mL}$ distilled water, generating a suspension and it was separated into various fractions by using solvents of increasing polarity in separating funnel, resulting in $n$-hexane (4g), Chloroform (5g), Ethyl acetate (11 g), $n$-butanol (10g) and aqueous (20g) fractions.

Preliminary Phytochemical analysis

Preliminary phytochemical analysis of the ethanolic extract and fractions were carried out for the presence of alkaloids, carbohydrates, flavonoids, glycosides, sterols, terpenoids, tannins, phenols and saponin by using standard procedures $^{13}$.

\section{Cytotoxicity effect \\ Cell culture}

HT- 29 tumor cell lines from human colon adenocarcinoma and 3T3 from non-tumorigenic, $\mathrm{BALB} / \mathrm{c}$ mouse embryo cells, cell lines were cultivated at the Laboratory of Immunology and Virology, Universidad Peruana Cayetano Heredia (UPCH). HT29 and 3T3 cell lines were grown in Dulbecco's Modified Eagle Medium supplemented with $10 \%$ fetal calf serum and as an antibiotic was used $50 \mu \mathrm{g} / \mathrm{mL}$ gentamycin in humidified $5 \% \mathrm{CO}_{2} / 95 \%$ air at $37^{\circ} \mathrm{C}$ under good laboratory practices conditions.

\section{Cytotoxicity assay}

The cytotoxic activity was performed by using the procedure of de Carvalho et al. ${ }^{14} \mathrm{~A}$ 96well tissue culture plate was taken and each of its well was inoculated with $3000-5000$ cells in their corresponding medium and was incubated at $37^{\circ} \mathrm{C}$ for 24 hours. Meanwhile, a mixture of the crude ethanolic extract and fractions (hexane fraction; chloroform fraction; ethyl acetate fraction; butanol
Table 2. Cytotoxicity of ethanolic extract and fractions of Dodonaea viscosa on human tumor cell lines

\begin{tabular}{lcc}
\hline \multirow{2}{*}{$\begin{array}{l}\text { Cytotoxic } \\
\text { samples }\end{array}$} & \multicolumn{2}{c}{ Values of $\mathrm{IC}_{50}(\mu \mathrm{g} / \mathrm{mL})^{\mathrm{A}}$} \\
\cline { 2 - 3 } & $\begin{array}{c}\text { Tumor cell } \\
\text { lines } \\
\text { HT-29 }\end{array}$ & $\begin{array}{c}\text { Mouse embryo } \\
\text { normal cells } \\
3 T 3\end{array}$ \\
\hline 1 & $10.52 \pm 2.5^{*}$ & $38.21 \pm 2.1$ \\
2 & $>250$ & $40.11 \pm 1.1$ \\
3 & $15.12 \pm 2.0^{*}$ & $182.14 \pm 2.1$ \\
4 & $38.52 \pm 2.69$ & $25.0 \pm 2.0$ \\
5 & $40.22 \pm 2.0$ & $35.4 \pm 1.0$ \\
6 & $120.00 \pm 5.0$ & $100.8 \pm 1.5$ \\
5 -FU & $0.33 \pm 0.01$ & $<0.24$ \\
\hline
\end{tabular}

$1=$ ethanolic extract; $2=n$-hexane fraction; $3=$ chloroform fraction; $4=$ ethyl acetate fraction; $5=n$-butanol fraction; $6=$ aqueous fraction. $5-\mathrm{FU}=5$-Flurouracil.

AValues were expressed as mean $\pm S D(n=3) . * P<0.05$, significant difference as compared to standard drug 5-FU.

fraction and aqueous fraction) with concentrations equivalents to $0-250 \mu \mathrm{g} / \mathrm{mL}$ and as control drug 5-FU $(0-62.5 \mu \mathrm{g} / \mathrm{mL})$ were dissolved in dimethyl sulfoxide and incubated at $37^{\circ} \mathrm{C}$ with $5 \% \mathrm{CO}_{2}$ and 95\% air for 48 hours. HT-29 and 3T3 cell lines were fixed with $10 \%$ trichloroacetic acid (TCA) and was stained with sulforhodamine $B$ (SRB) dye for 20 minutes. Cells were washed with $1 \%$ acetic acid to remove the excess dye and subsequently the protein-bound dye was solubilized by adding $10 \mathrm{mM}$ solution of Tris buffer $(\mathrm{pH} 10.5)$. Finally, samples were read at $510 \mathrm{~nm}$ by using a microplate reader. The results obtained by triplicate were expressed as inhibitory concentration $50\left(\mathrm{IC}_{50}\right)$, which was determined by linear regression analysis.

\section{Statistical analysis}

The cytotoxic effect against two cell lines (HT-29 and 3T3) were analyzed three times and the results were expressed as mean \pm standard deviation (SD). For graphical and statistical analysis, SPSS 22.0 and Microsoft Excel 2016 were used as statistical software. One-way ANOVA followed by a post hoc Tukey test were used as statistical test with a significance $\mathrm{P}<0.05$.

\section{RESULTS}

Determination of Phytochemical constituents

Qualitative screening of $D$. viscosa for 
the presence of phytochemical constituents was carried out by using its crude ethanolic extract and fractions. The results are presented in Table 1, which shows that the plant has alkaloids, sterols, carbohydrates, terpenoids, flavonoid, tannins, phenols, glycosides and saponin.

\section{Cytotoxic assay}

The $\mathrm{IC}_{50}$ values of the ethanolic extract and fractions of $D$. viscosa leaves as well as 5-FU (antitumor drug) on tumor cell lines are shown

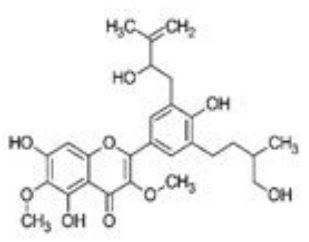

Dodoviscin A

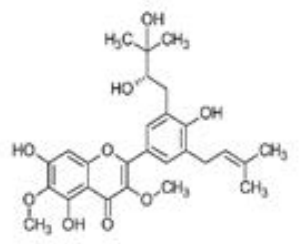

Dodoviscin D

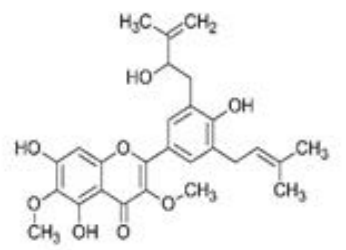

Dodoviscin B

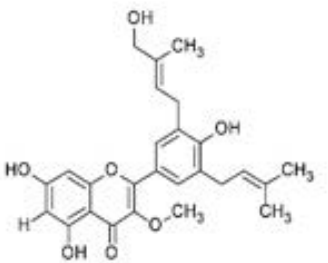

Dodoviscin E<smiles>COc1c(-c2cc(CC=C(C)C)c(O)c(CCC(C)CO)c2)oc2cc(O)cc(O)c2c1=O</smiles>

Dodoviscin $\mathrm{H}$ in table 2. The chloroform fraction and ethanol extract showed IC $\mathrm{I}_{50}$ values below of $20 \mu \mathrm{g} / \mathrm{mL}$ for HT-29 cell lines, but less than 5-FU. All fractions and crude ethanol extract did not present any evidence of cytotoxicity on 3T3 cell line.

\section{DISCUSSION}

Several phytochemical studies of $D$. viscosa have been reported, which determined the presence of flavonoids, terpenes, lactones, and<smiles></smiles>

Dodoviscin G<smiles></smiles>

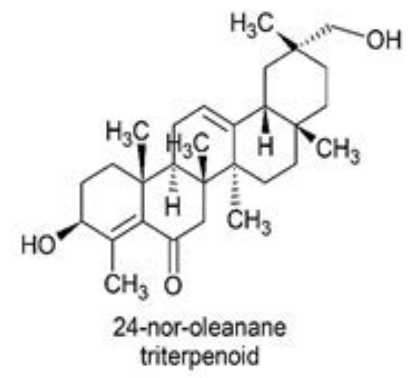

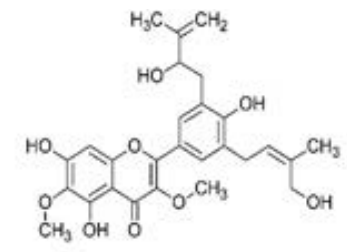

Dodoviscin C

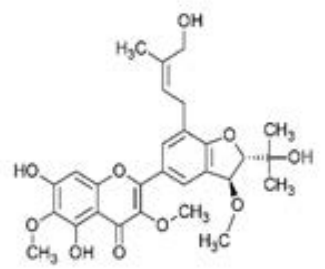

Dodoviscin F
Dodoviscin I

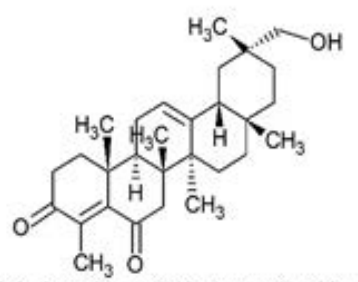

3,6-dioxo-24-nor4, 12-oleanadien-29-ol

Fig. 2b. Chemical constituents reported in Dodonaea viscosa Jacq leaves 
alkaloids. Our results based on fractions are similar to other works reported in the literature. From the fraction chloroform extracted one flavonoid named 3, 5, 7, 3',4'-pentahydroxy-flavone, hautriwaic acid. These compounds showed a high antimicrobial activity against gram positive and negative bacterial ${ }^{15}$.

Prenylated flavonoids present in $D$. viscosa leaves have demonstrated anti-inflammatory effect due to several types of Dodoviscins isolated of the soluble fraction from the ethyl acetate extraction ${ }^{16}$. Otherwise, exist a relationship between the gut microbiota and colorectal cancer, when this microbiota is altered a chronic inflammation could be the starting point of the colorectal cancer progression ${ }^{17,18}$.

The cytotoxic effect showed for ethanolic extract and chloroform fraction could be linked to phytochemical constituents such as phenolic compounds, flavonoids, tannins, saponins or alkaloids; furthermore, many reports attributed that flavonoids consumption could decrease the risk of colorectal cancer ${ }^{19}$, while it is very difficult to argue that the same can occur with other types of cancer as breast cancer or lung cancer. Otherwise, quercetin, myricetin, apigenin and luteolin was not associated between their consumption and the incidence of any type of cancer or mortality from this cause. Although, a positive relationship was found between their intake and mortality from stomach cancer ${ }^{20}$. The results showed in Table 2 corresponds to values less than $20 \mu \mathrm{g} / \mathrm{mL}$ and according to the U.S. National Cancer Institute $(\mathrm{NCl})$, both extracts are recognized as potential cytotoxic agents, although is necessary to evaluate in another colorectal cancer cell line ${ }^{21}$.

There were several studies related to cytotoxicity of $D$. viscosa, an in-vitro study showed that the synthesized AuNPs (gold nanoparticles) using Dodonaea viscosa leaf extract inhibited the growth of A549 NSCLC cells (adenocarcinomic human alveolar basal epithelial cells), being the most active the methanol extract with the $\mathrm{IC}_{50}$ values of $4.0 \mu \mathrm{g} / \mathrm{ml}^{22}$. Dodoneasides $A$ and $B$ isolated from the ethanol extract of $D$. viscosa roots showed antiproliferative activity against the A2780 human ovarian cancer cell line ${ }^{23}$. Finally, Dodoviscin $A$ isolated of the aerial parts from $D$. viscosa inhibits melanogenesis in mouse b16-f10 melanoma cells ${ }^{24}$.
Our limitations in this study are focused on the cytotoxic activity due to only one tumor cell line of colorectal cancer was used in the assay and we did not isolate the phytochemicals of the ethanol extract and its fractions.

\section{CONCLUSION}

This study concluded that the ethanolic extract and the chloroform fraction from $D$. viscosa presented a cytotoxic effect on HT29-cell line with values less than $20 \mu \mathrm{g} / \mathrm{mL}$. Furthermore, our study did not show cytotoxicity on $3 \mathrm{~T} 3$ cells, which it could demonstrate that the phytochemicals of $D$. viscosa are selective to colorectal cancer cells. Further studies are needed to complement mechanisms and experimental studies with rodents.

\section{ACKNOWLEDGMENTS}

All listed author(s) are thankful to their representative universities/institutes for providing the related support to compile this work.

\section{CONFLICT OF INTEREST}

The authors declare that there is no conflict of interest.

\section{AUTHORS' CONTRIBUTION}

All listed author(s) have made a substantial, direct, and intellectual contribution to the work, and approved it for publication.

\section{FUNDING}

None.

\section{ETHICS STATEMENT}

This article does not contain any studies with human participants or animals performed by any of the authors.

\section{DATA AVAILABILITY}

Not applicable.

\section{References}

1. Vasaikar S, Huang C, Wang X, et al. Proteogenomic Analysis of Human Colon Cancer Reveals New Therapeutic Opportunities. Cell. 2019;177(4):10351049. doi: 10.1016/j.cell.2019.03.030

2. Tabung FK, Steck SE, Ma Y, et al. The association between dietary inflammatory index and risk of colorectal cancer among postmenopausal women: 
results from the Women's Health Initiative. Cancer Causes Control. 2015. doi: 10.1007/s10552-014-0515-y

3. Bray F, Ferlay J, Soerjomataram I, Siegel RL, Torre LA, Jemal A. Global cancer statistics 2018: GLOBOCAN estimates of incidence and mortality worldwide for 36 cancers in 185 countries. CA Cancer J Clin. 2018;68(6):394-424. doi: 10.3322/caac.21492

4. Kumar D, Sharma M, Verma S, Saroha K. Natural Polymers and Herbal Medicine Based Therapy for Colonic Diseases . Int J Herb Med. 2016;4(3):49-56.

5. Xiao ZM, Wang AM, Wang XY, Shen SR. Effects of ethanol extract of Radix Sophorae Flavescentis on activity of colon cancer HT29 cells. Afr J Tradit Complement Altern Med. 2013;10(5):352-355. doi: 10.4314/ajtcam.v10i5.22

6. Verhoeckx K, Cotter P, Lopez-Exposito I, et al. The Impact of Food Bioactives on Health. (Verhoeckx K, Cotter P, Lopez-Exposito I, et al., eds.). Cham: Springer International Publishing. 2015. doi: 10.1007/978-3319-16104-4

7. Maleki SJ, Crespo JF, Cabanillas B. Anti-inflammatory effects of flavonoids. Food Chem. 2019. doi: 10.1016/j. foodchem.2019.125124

8. Kim T, Song B, Cho KS, Lee IS. Therapeutic potential of volatile terpenes and terpenoids from forests for inflammatory diseases. Int J Mol Sci. 2020. doi: 10.3390/ijms21062187

9. Newman DJ, Cragg GM. Natural Products as Sources of New Drugs from 1981 to 2014. J Nat Prod. 2016;49(3):629-661. doi: 10.1021/acs. jnatprod.5b01055

10. Zyad A, Leouifoudi I, Tilaoui M, Mouse HA, Khouchani $M$, Jaafari A. Natural Products as Cytotoxic Agents in Chemotherapy against Cancer. Cytotoxicity. 2018. doi: 10.5772/intechopen.72744

11. Muhammad A, Tel-Cayan G, Ozturk M, et al. Biologically active flavonoids from Dodonaea viscosa and their structure-activity relationships. Ind Crops Prod. 2015;78:66-72. doi: 10.1016/j.indcrop.2015.10.011

12. Hossain MA. Biological and phytochemicals review of Omani medicinal plant Dodonaea viscosa. J King Saud Univ-Sci. 2019;31(4). doi: 10.1016/j.jksus.2018.09.012

13. Yadav RNS, Agarwala M. Phytochemical analysis of some medicinal plants. J Phytol 2011.
14. de Carvalho DD, Costa FTM, Duran N, Haun M. Cytotoxic activity of violacein in human colon cancer cells. Toxicol Vitr. 2006;20(8):1514-1521. doi: 10.1016/j.tiv.2006.06.007

15. Hamed Al Bimani BM, Hossain MA. A new antimicrobial compound from the leaves of Dodonaea viscosa for infectious diseases. Bioact Mater. 2020;5(3):602-610 doi: 10.1016/j.bioactmat.2020.04.006

16. Gao Y, Fang YD, Hai P, Wang F, Liu JK. Isoprenylated flavonoids and clerodane diterpenoids from Dodonaea viscosa. Nat Products Bioprospect. 2013;3:250-255. doi: 10.1007/s13659-013-0053-4

17. Louis P, Hold GL, Flint HJ. The gut microbiota, bacterial metabolites and colorectal cancer. Nat Rev Microbiol. 2014;12:661-672. doi: 10.1038/nrmicro3344

18. Sun J, Kato I. Gut microbiota, inflammation and colorectal cancer. Genes Dis. 2016;3(2):130-143. doi: 10.1016/j.gendis.2016.03.004

19. Dahmus JD, Kotler DL, Kastenberg DM, Kistler CA. The gut microbiome and colorectal cancer: A review of bacterial pathogenesis. J Gastrointest Oncol. 2018;9(4). doi: 10.21037/jgo.2018.04.07

20. Alvarez E, Cambeiro O. Actividad biologica de los flavonoides ( I ). Accion frente al cancer. Offfarm. 2003.

21. Skehan $P$, Storeng $R$, Scudiero D, et al. New colorimetric cytotoxicity assay for anticancer-drug screening. J Natl Cancer Inst. 1990;82(13):1107-1112. doi: 10.1093/ jnci/82.13.1107

22. Anandan M, Gurumallesh Prabu H. Dodonaea viscosa Leaf Extract Assisted Synthesis of Gold Nanoparticles: Characterization and Cytotoxicity Against A549 NSCLC Cancer Cells. J Inorg Organomet Polym Mater. 2018;28(3):932-941. doi: 10.1007/s10904-018-0799-6

23. Cao $\mathrm{S}$, Brodie $\mathrm{P}$, Callmander $\mathrm{M}$, et al. Antiproliferative triterpenoid saponins of Dodonaea wiscosa from the madagascar dry forest. J Nat Prod. 2009;72(9):17051707. doi: $10.1021 / \mathrm{np} 900293 x$

24. Yan G, Zhu J, Zhang L, et al. Dodoviscin a inhibits melanogenesis in mouse b16-f10 melanoma cells. Planta Med. 2013;79(11):933-938. doi: 10.1055/s0032-1328649 